Article

\title{
Before and after the Quarantine: An Approximate Study on the Psychological Impact of COVID-19 on the Italian Population during the Lockdown Period
}

\author{
Lorena Marotta ${ }^{1,+}$, Andrea Pesce ${ }^{1,+}$ and Andrea Guazzini ${ }^{2, *,+}$ \\ 1 Department of Education, Languages, Intercultures, Literatures and Psychology, and LabCom, \\ Research and Action for Psychosocial Wellbeing, 50135 Firenze, Italy; lorena.marotta@stud.unifi.it (L.M.); \\ andrea.pesce@stud.unifi.it (A.P.) \\ 2 Center for the Study of Complex Dynamics (CSDC), and Department of Education, Languages, Intercultures, \\ Literatures and Psychology, University of Florence, 50121 Firenze, Italy \\ * Correspondence: andrea.guazzini@unifi.it \\ + These authors contributed equally to this work.
}

Received: 29 October 2020; Accepted: 8 December 2020; Published: 15 December 2020

\begin{abstract}
COVID-19 (Corona-Virus Disease 2019) in Italy and the measures that were adopted to contain its diffusion had a strong impact on people's quality of life and mental health. The objective of the study was to quantify the psychological impact of the lockdown period on the general Italian population during the two weeks when the COVID-19 emergency in Italy was at its peak. The study (1556 adults) was conducted from April 6th to April 12th, 2020. A survey was developed through Google Forms in order to assess different psychological measures (Self Efficacy, Locus of Control, Social Connectedness, Sense of Virtual Community, Flourishing, Positive and Negative Affect, Life Satisfaction, and Risk Propensity). The results were then compared to reference data. Thelockdown period increased arousal mainly for negative emotions, but also for positive emotions, and quality of life seemed to be reduced. From a psychosocial point of view, while social connectedness has decreased during lockdown, probably because of isolation and social distancing, the virtual social community seemed to increase in the same period. Interestingly, we revealed how self efficacy increased during the lockdown period, and, at the same time, the Locus of control appeared as externalized, and the risk propensity as reduced. The results are discussed considering previous literature, and a coherent theoretical framework is proposed in order to refine the forecasting model for the psychological impact of the lockdown.
\end{abstract}

Keywords: COVID-19; lockdown; pandemics; COVID psychological impact; community resilience

\section{Introduction}

On March 11, 2020 , the World Health Organization declared the COVID-19 virus as a global pandemic [1]. During the initial stages of the emergency, Italy saw a rapid and massive spread of the contagion, which initially led the country to be the one most affected by the virus, with many cases and a large number of causalities since February 20, 2020 [2]. In order to limit the spread of the virus, the Italian Government issued restrictive measures that led to the gradual lockdown of the country, with a severe impact on both the economy and general population [3]. People were required by law to stay home, except for work and health related reasons, leaving the population to face an unprecedented situation: from literature, we know that times of economical uncertainty can have a negative impact on mental health $[4,5]$.

Moreover, in the literature, we also find negative effects of pandemics and quarantine: such literature reports an overall increase in levels of distress and other negative feelings, like boredom, 
loneliness, and mood disorders [6]; however, this emergency is unlike any other that we might have faced in the past. We can find a most prominent difference in the fact that, in this time and age, we can observe a large scale diffusion in the use of Social Networking Sites (SNS) and communication channels. This allowed for people, despite social distancing being mandatory and necessary, to still come into contact with each other. Social media mitigated the effects of social distancing, providing mental health support, solidarity, and useful information regarding quarantine and other practical measures to adopt [7,8], as well as the direct and indirect benefits of an extended network [9]. In the meanwhile, people could also stay updated (i.e., informational support) on the latest news [10]. However, this brought the risk of encountering fake news [11] or being overwhelmed by information [12,13].

The COVID-19 outbreak lowered the quality of life for many individuals, both because of the virus itself as well as because of the quarantine measures that were adopted by the government, determining a lower life satisfaction [14,15] and lower well-being [16]. There is also an increase in suicidal behaviour [17] and a clear increase of negative emotions-like anxiety, depression, and indignation. [10,15,18-20].

Dunning and Pownall [21] analyze risk perception and locus of control: participants who perceived themselves as low risk of contracting the virus generally attributed this to more internal and dispositional factors. Variables that are protective against the negative effects of the pandemics are also functional coping strategies $[14,18,22]$ and social support, since it strengthens the value of social capital and brings better results on health interventions and greater adherence to social distancing protocols [23]. It is associated with a reduction in anxiety and stress, as well as an increase in self-efficacy [20], which, in turn, seems to be associated with an increase in protective behaviors [24].

The total lockdown that was established by Italy, modeled after the measures that were adopted in China, has led to a gradual increase in psychological distress (e.g., anxiety and depression, which are higher than the average European epidemiological data [25]), a reduction in overall well-being, and to a general symptomatology of Post Traumatic Stress disorder, with a plausible relation between days spent in quarantine and the amount of perceived distress [26]. Even those who have reported a larger social support hold stronger concerns that are related to the health hazard posed by the virus, as people with a larger social network might be acquainted with a higher number of COVID-19 patients [27]. Despite this, the population still appears to be confident and respectful towards both state institutions and the restrictive measures [26]. However, we noticed a lack of literature investigating in Italy some variables that were, instead, highlighted in other cultures.

For our study, we decided to measure the psychological impact of the lockdown period on the general Italian population during the two weeks in which the COVID-19 emergency in Italy was at its peak, focusing on self-efficacy, locus of control, risk propensity, positive and negative affects, social connectedness, virtual sense of community, and different dimensions of well-being. The aim of the present study is to reveal the coping strategies that were adopted by the Italian population after the first month of lockdown, and their effectiveness in mitigating the impact of restrictive measures following the promulgation of the "Io resto a casa" ("I'm staying home") decree [28], to both understand the resilience potential of the Italian Community and design possible interventions to mitigate the impact of COVID19 on people's well-being. We hypothesize, according to the existing literature, a reduction in general well-being in all of the dimensions that we took into consideration, as well as lower self-efficacy and a lower social-connectedness as a direct consequence of the quarantine period. We also expect to find a prevalence in negative emotions, as well as a reduced risk propensity.

\section{Methods}

\subsection{Setting and Participants}

The study was conducted through the diffusion of an online survey, and it aims to advance the research on the psychological effects of the lockdown on dimensions not yet investigated within the Italian population: this allows for a frame of reference for any subsequent studies. The study sample 
consisted of 1556 adults that were residents of Italy. All of those who had an internet connection, who were over 18 years of age, fluent in Italian, and residing in Italian territory at the time of completion could participate.

\subsection{Procedure and Survey Development}

The participants in the study were selected through a 'snowball' sampling [29]. Since the lockdown prevented the researchers from having a direct, face-to-face contact with subjects, it was decided to use an online questionnaire: this inevitably had the limit of only being able to reach a sample that had some degree of literacy in regards to Internet and technology; however, this method also allowed for us to guarantee anonymity, and to maximise the respondents' self disclosure [30,31] and reduce their social desirability [32].

The online questionnaire was developed through Google Forms, and the consent form was attached to it. The URL address to the questionnaire was sent by email, WhatsApp, and other social networking sites, by the researchers towards a list of people that are affiliated with the research laboratory. After that, the participants were also invited to spread the address, so that it could reach subjects that were not initially contacted by the researchers. The questionnaires were administered to the participants according to the Italian law's requirements of privacy and informed consent (Law Decree DL-101/2018), EU regulation (2016/699), and APA guidelines. Moreover, the ethical commission of the University of Florence approved the study (protocol number: 0092811). The questionnaire could only be completed after reading and accepting the terms within the consent form, presented after the study information. The time for completion ranged from 8 to $25 \mathrm{~min}$, and the participants were allowed to withdraw at any moment and no personal data were saved. The study was conducted from April 6th to April 12th.

\subsection{Measures}

The online questionnaire was structured into three main sections: socio-demographic questions, questions about experiences with COVID-19, and psychological questions. The psychological impact of the quarantine period was quantified and then compared to reference data that were taken from the most recent and closest to our sample data available on these psychological instruments, in order to estimate the impact of the situation on the population through the following scales:

To measure Self Efficacy, we used the Generalized Self Efficacy Scale (GSE) by Schwarzer et al. [33], a self report measure of one's ability to deal with stressful situations or demands. It is a brief questionnaire that consists of 10 items on a five-point Likert scale. The score is calculated by adding together the answers to all of the items: a higher score in this questionnaire is an indication of higher Self Efficacy. The reference data were taken from a study by Guazzini et al. [34], in which its internal reliability coefficient is $\alpha=0.90$. In our study, the internal reliability coefficient is $\alpha=0.82$.

We measured Locus of Control while using the Locus of Control of Behaviour (LCB) by Craig et al. [35]. Locus of control is the extent to which a person perceives a situation as being a consequence of their actions and under their control: the higher the score in this questionnaire, the more the Locus of Control is external. It consists of 17 items with a six-point rating scale, and the score is calculated by adding the items that are related to external Locus of Control and subtracting the ones that are related to an internal Locus of Control. The reference data were taken from a study by Farma and Cortivonis [36], in which the internal reliability coefficient is $\alpha=0.71$. In our study, it is $\alpha=0.74$.

In order to measure Social Connectedness we used the Social Connectedness scale-Revised (SCS-R) by Lee and Robbins [37]. The scale assesses experiences of closeness in interpersonal contexts, and it consists of 20 items with a six-point rating scale. Ten of these items are worded negatively, and the others positively: the negative ones are reverse scored, and a higher score indicates a greater social connectedness. The reference data were taken from a study by Capanna et al. [38], in which the internal reliability coefficient is $\alpha=0.88$. In our study, the internal reliability coefficient is $\alpha=0.76$.

We assessed sense of community in virtual environments using the Sense of Virtual Community 
Scale (SoVc) by Blanchard [39]. It is an 18-item scale on a five-point Likert scale measuring one's sense of belonging in a virtual community. The reference data were taken by a study by Guazzini et al. [40], in which its internal reliability coefficient is $\alpha=0.90$ and, in our study, the internal reliability coefficient is $\alpha=0.81$.

To measure the eudaimonic well-being, we used the Flourishing Scale (FS) by Diener et al. [41]. This scale is useful for obtaining an overview of one's perception of their positive functioning: it consists of 8 items with a seven-point rating scale. The score is obtained by adding all the items: a higher score means that the subjects see themselves in a more positive light. The reference data were taken from a study by Giuntoli et al. [42], in which its internal reliability coefficient is $\alpha=0.90$ and, in our study, the internal reliability coefficient is $\alpha=0.79$.

In order to assess the hedonic/cognitive well-being, we used the Positive and Negative Affect Schedule (PANAS) by Watson et al. [43]. It consists of two 10-item mood scales: subjects must answer while keeping in mind to what extent they felt every emotion in a specific period of time, with answers in a five-point scale. The Italian validation by Terraciano et al. [44] from which we took the reference data differentiates between state and trait: we selected state, as we asked our participants to reply according to the last two weeks. In this study, the internal reliability coefficient is $\alpha=0.76$; in the present study, the internal reliability coefficient is $\alpha=0.72$.

We measured hedonic/affective well-being with the Satisfaction With Life Scale (SWLS) by Diener et al. [45]. The five item scale on a seven-point rating measures satisfaction with life as a whole: the first three items refer to present satisfaction, and the remaining two to the past. The Italian translation of this scale, from which we took the reference data, was validated by Di Fabio and Gori [46], in which its internal reliability coefficient is $\alpha=0.85$. In our study, this coefficient is $\alpha=0.80$.

Finally, in order to measure risk-taking tendencies we used the General Risk Propensity Scale (GRiPS) by Zhang et al. [47]. It is a short scale that consists of eight items on a five-point rating scale. We used the original work by Zhang et al. [47] to retrieve the reference data: in this study, the internal reliability coefficient is $\alpha=0.92$ and, in our study, it is $\alpha=0.90$.

\subsection{Statistical Analysis}

Experimental data were preliminarily described by means of descriptive statistics, and prevalence data were assessed for each dimension reported. Subsequently, all of the experimental variables were pre-processed in order to control the preconditions for the further inferential analysis, in particular the normality for the continuous variable distributions and the balance of discrete variables was considered. For those variables reporting values of skeweness and kurtosis out of the range $(-1,1)$, a logarithmic transformation was operated to normalize the distribution. Finally, in order to test the experimental hypotheses, the T-student test for independent samples was adopted to compare our sample data with reference data for each psychological dimension, as well as to estimate the relations between discrete and continuous psychological dimensions. We adopted the Hedges $g$ coefficient in order to estimate the effect size [48]. In order to investigate the relations between unbalanced variables and continuous variables, we first discretized the continuous observable when considering the median as the reference value, and we adopted the $\chi^{2}$ test. Finally, continuous variables were compared by means of Pearson $r$. bivariate correlation.

\section{Results}

\subsection{Socio-Demographic Characteristics of the Sample and Questions about Experiences with COVID-19}

The socio-demographic information included age $(\mathrm{m}=27.88$; DS $=10.33)$, sex (female $83.4 \%)$, level of education, marital status, annual income, occupation, questions about size, and characteristics of the household and about the experiences of participants with COVID-19. The sample subjects are predominantly graduates (high school 49.9\%), in a relationship without cohabiting (39.3\%), and are 
students as a profession (48.4\%). The majority of respondents have an annual income of $<10 k €(52.8 \%)$. When considering the global pandemic, it was investigated with whom they lived during the lockdown period (family: $68.6 \%$ ); most of the respondents rated their family members as more vulnerable to the virus $(67.2 \%)$ and, when considering the spread of the virus, $54.3 \%$ of the sample did not have direct contact with Covid-19, while $34.8 \%$ had acquaintances that have been infected. Table 1 reports a complete description of the sample. We proceeded, when necessary, to normalize data through a logarithmic transformation in order to verify the relations between socio-demographic dimensions and operative variables by means of inferential statistics [49].

Table 1. Socio-demographic characteristics and experiences with COVID19.

\begin{tabular}{|c|c|c|c|c|}
\hline Continuous Dimensions & Mean & S.D. & Skeweness & Kurtosis \\
\hline Age & 27.88 & 10.33 & 2.03 & 4.05 \\
\hline Age (Log) & 3.27 & 0.30 & 1.07 & 1.08 \\
\hline Education & 14.48 & 2.79 & -0.19 & 0.13 \\
\hline Annual family income & 3.65 & 1.08 & 0.92 & 0.65 \\
\hline Household size & 3.31 & 1.19 & -0.19 & -0.46 \\
\hline Discrete Dimensions & \multicolumn{3}{|c|}{ Observable } & Percentage \\
\hline \multirow{2}{*}{ Sex } & \multicolumn{3}{|c|}{ Male } & $16.6 \%$ \\
\hline & \multicolumn{3}{|c|}{ Female } & $83.4 \%$ \\
\hline \multirow{5}{*}{ Marital Status } & \multicolumn{3}{|c|}{ Single } & $37.5 \%$ \\
\hline & & $39.3 \%$ \\
\hline & \multicolumn{2}{|c|}{ Married or cohabiting } & & $21.4 \%$ \\
\hline & \multicolumn{3}{|c|}{ Divorced or separated } & $1.5 \%$ \\
\hline & \multicolumn{3}{|c|}{ Widow } & $0.3 \%$ \\
\hline \multirow{6}{*}{ Occupation } & \multicolumn{3}{|c|}{ Unemployed } & $15.1 \%$ \\
\hline & \multicolumn{3}{|c|}{ Student } & $48.4 \%$ \\
\hline & \multicolumn{3}{|c|}{ Autonomous worker } & $10.0 \%$ \\
\hline & \multicolumn{3}{|c|}{ Public employed } & $5.4 \%$ \\
\hline & \multicolumn{3}{|c|}{ Private employed } & $19.4 \%$ \\
\hline & \multicolumn{3}{|c|}{ Retired } & $1.7 \%$ \\
\hline \multirow{4}{*}{ Cohabiting } & \multicolumn{3}{|c|}{ Alone } & $8.9 \%$ \\
\hline & \multicolumn{3}{|c|}{ Partner } & $14.8 \%$ \\
\hline & \multicolumn{3}{|c|}{ Family } & $68.6 \%$ \\
\hline & \multicolumn{3}{|c|}{ Friend/Roommates } & $7.7 \%$ \\
\hline \multirow{2}{*}{ Cohabiting elder or vulnerable people } & \multicolumn{3}{|c|}{ Yes } & $10.3 \%$ \\
\hline & \multicolumn{3}{|c|}{ No } & $89.7 \%$ \\
\hline \multirow{2}{*}{ Direct contact with COVID19 } & \multicolumn{3}{|c|}{ Yes } & $45.7 \%$ \\
\hline & \multicolumn{3}{|c|}{ No } & $54.3 \%$ \\
\hline \multirow{4}{*}{ Type of contact with COVID19 } & \multicolumn{3}{|c|}{ Infected acquaintances } & $34.8 \%$ \\
\hline & \multirow{2}{*}{\multicolumn{3}{|c|}{$\begin{array}{l}\text { Infected family member } \\
\text { Infected friends }\end{array}$}} & $7.0 \%$ \\
\hline & & & & $9.7 \%$ \\
\hline & & Infecte & pondent & $0.8 \%$ \\
\hline
\end{tabular}

\subsection{Psychological Characteristics of the Sample}

We investigated the following psychological measures: locus of control, self efficacy, virtual sense of community, social connectedness, risk propensity, and different dimensions of well-being: eudaimonic well-being, hedonic and cognitive well-being, and hedonic and affective well-being (Table A1, in Appendix A) were tested in the sample $(n=1556)$ during the period of time that went from April 6th to April 12th; in other words, when the COVID-19 emergency in Italy was at its peak, and the subjects in the sample were still facing the lockdown period without yet knowing when it would have ended. We tested the relations between continuous socio-demographic and psychological characteristic of the sample, in particular, in relation to age, education, income, and household size, 
as reported in Table 2 . The correlations are generally very weak or absent, and all of the values are smaller than 0.2 in absolute value.

Table 2. Pearson $r$. correlations between psychological variables of the sample and sociodemographic features.

\begin{tabular}{|c|c|c|c|c|}
\hline Psychological Dimension & Age (Log) & Education & Income & Household Size \\
\hline Self Efficacy & $0.12^{(p .<0.001)}$ & $0.10^{(p .<0.001)}$ & $0.10^{(p .<0.001)}$ & $-0.08^{(p .<0.001)}$ \\
\hline External LOC & $-0.07^{(p .=0.009)}$ & $-0.13^{(p .<0.001)}$ & $-0.04(p .=0.138)$ & $\left.0.02^{(p .}=0.460\right)$ \\
\hline Social Connectedness & $\left.0.05^{(p .}=0.037\right)$ & $0.12^{(p .<0.001)}$ & $\left.0.04^{(p .}=0.156\right)$ & $\left.-0.01^{(p .}=0.642\right)$ \\
\hline Virtual SOC & $0.03^{(p .=0.163)}$ & $0.05^{(p .=0.033)}$ & $0.02^{(p .=0.319)}$ & $-0.07^{(p .=0.003)}$ \\
\hline Flourishing & $-0.07^{(p .=0.006)}$ & $-0.01^{(p .=0.597)}$ & $-0.01^{(p .=0.930)}$ & $\left.-0.03^{(p .}=0.177\right)$ \\
\hline PANAS Positive & $0.03^{(p .=0.211)}$ & $0.11^{(p .<0.001)}$ & $\left.0.03^{(p .}=0.162\right)$ & $\left.-0.02^{(p .}=0.469\right)$ \\
\hline PANAS Negative & $-0.18^{(p .<0.001)}$ & $-0.10^{(p .<0.001)}$ & $-0.08^{(p .<0.001)}$ & $0.10^{(p .<0.001)}$ \\
\hline Satisfaction with life & $0.01^{(p .=0.953)}$ & $0.08^{(p .<0.001)}$ & $0.13^{(p .<0.001)}$ & $\left.0.02^{(p .}=0.510\right)$ \\
\hline Risk Propensity & $0.11^{(p .<0.001)}$ & $-0.01^{(p .=0.697)}$ & $0.01^{(p .=0.744)}$ & $\left.-0.02^{(p .}=0.335\right)$ \\
\hline
\end{tabular}

Because of the unbalancing of the discrete socio-demographic and COVID-19 related variables, we adopted the $\chi^{2}$ statistics discretizing the psychological variables when considering the median values in order to verify the relations of such dimensions with the psychological variables (Table 3). In line with the literature, males are characterized by a greater self efficacy, while, peculiarly, presenting a lower risk propensity. Married and divorced respondents presented a greater self efficacy, while single ones presented a virtual sense of community as well as a lower risk propensity. In particular, risk propensity appears to be greater for widows. Occupational status appears to be related with self efficacy, with unemployed, student, and public worker respondents being characterized by lower values. Concerning risk propensity, students present a lower value, while public workers and retired respondents presented a greater one. The cohabiting condition only showed a relation with a virtual sense of community, with people living with their families reporting lower values. Direct experiences with COVID-19 are related with several psychological variables that are not related with well-being. In particular, people that had previous contacts with COVID-19 in general are characterized by greater social connectedness and a greater risk propensity. Those who had an infected relative reported a higher self efficacy, while those who had an infected friend are characterized by greater social connectedness.

The dimensions related with well-being are compared with the socio-demographic and COVID-19 related features presented in Table 4 . The cognitive eudaimonic component of well-being revealed by the Flourishing construct was significantly greater in the male subsample and significantly lower in retired people, while the eudaimonic-affective component, as measured with PANAS, appears greater again for males as well as for married and divorced people, while it appears to be significantly lower for unemployed people. Finally, the hedonic well-being, which was captured by the satisfaction with life construct, was greater for married people and retired workers, and again lower for unemployed people. 
Table 3. Relations between psychological variables not related to well being, and discrete socio-demographic and COVID-19 related variables. For the sake of simplicity, we only reported in table the percentages of observations that were characterized by greater values than the median.

\begin{tabular}{|c|c|c|c|c|c|c|c|c|c|}
\hline \multicolumn{2}{|c|}{$\begin{array}{c}\text { Psychological } \\
\text { Dimension }\end{array}$} & \multicolumn{2}{|c|}{$\begin{array}{l}\text { Self } \\
\text { Eff. }\end{array}$} & \multicolumn{2}{|c|}{$\begin{array}{l}\text { Social } \\
\text { Conn. }\end{array}$} & \multicolumn{2}{|c|}{$\begin{array}{l}\text { Virt. } \\
\text { SOC }\end{array}$} & \multicolumn{2}{|c|}{$\begin{array}{c}\text { Risk } \\
\text { Propensity }\end{array}$} \\
\hline & & $\%$ & $x^{2}$ & $\%$ & $x^{2}$ & $\%$ & $x^{2}$ & $\%$ & $x^{2}$ \\
\hline Sex & $\begin{array}{l}\text { Male } \\
\text { Female }\end{array}$ & $\begin{array}{l}57.7 \% \\
42.9 \% \\
\end{array}$ & $18.74 * * *$ & & s & & ns & $\begin{array}{l}35.2 \% \\
50.1 \% \\
\end{array}$ & $18.95^{* * *}$ \\
\hline Status & $\begin{array}{c}\text { Single } \\
\text { Relationship } \\
\text { Married } \\
\text { Divorced } \\
\text { Widow }\end{array}$ & $\begin{array}{l}44.6 \% \\
41.0 \% \\
52.3 \% \\
78.3 \% \\
40.0 \%\end{array}$ & $21.29 * * *$ & & is & $\begin{array}{l}44.1 \% \\
52.3 \% \\
55.0 \% \\
60.9 \% \\
60.0 \%\end{array}$ & 14.01 ** & $\begin{array}{l}42.5 \% \\
49.3 \% \\
53.2 \% \\
52.2 \% \\
60.0 \%\end{array}$ & 11.35 * \\
\hline Occupation & $\begin{array}{c}\text { Unemployed } \\
\text { Student } \\
\text { Autonomous } \\
\text { Public } \\
\text { Private } \\
\text { Retired }\end{array}$ & $\begin{array}{l}40.4 \% \\
42.9 \% \\
51.9 \% \\
42.9 \% \\
51.3 \% \\
57.7 \%\end{array}$ & $13.01 *$ & & is & & ns & $\begin{array}{l}51.1 \% \\
42.9 \% \\
52.6 \% \\
60.7 \% \\
49.0 \% \\
69.2 \%\end{array}$ & $20.26^{* * *}$ \\
\hline Cohabiting & $\begin{array}{l}\text { Alone } \\
\text { Partner } \\
\text { Family } \\
\text { Friends }\end{array}$ & & ns & & is & $\begin{array}{l}54.7 \% \\
58.7 \% \\
47.0 \% \\
53.3 \%\end{array}$ & $12.42 * *$ & & ns \\
\hline $\begin{array}{l}\text { COVID19 } \\
\text { Contact }\end{array}$ & $\begin{array}{l}\text { Yes } \\
\text { No }\end{array}$ & & ns & $\begin{array}{l}51.3 \% \\
44.4 \%\end{array}$ & $7.50^{* *}$ & & ns & $\begin{array}{l}51.2 \% \\
44.9 \% \\
\end{array}$ & $5.96 *$ \\
\hline $\begin{array}{l}\text { COVID19 } \\
\text { Relative }\end{array}$ & $\begin{array}{l}\text { Yes } \\
\text { No }\end{array}$ & $\begin{array}{l}56.9 \% \\
44.4 \%\end{array}$ & $6.33^{* *}$ & & is & & ns & & ns \\
\hline $\begin{array}{l}\text { COVID19 } \\
\text { Friend }\end{array}$ & $\begin{array}{l}\text { Yes } \\
\text { No }\end{array}$ & & ns & $\begin{array}{l}58.3 \% \\
46.4 \%\end{array}$ & $7.71^{* *}$ & & ns & & ns \\
\hline
\end{tabular}

Table 4. Relations between well being with discrete socio-demographic and COVID-19 related variables. For the sake of simplicity, we only reported the percentages of observations that were characterized by a greater value than the median.

\begin{tabular}{|c|c|c|c|c|c|c|c|c|c|}
\hline \multicolumn{2}{|c|}{$\begin{array}{c}\text { Psychological } \\
\text { Dimension }\end{array}$} & \multicolumn{2}{|c|}{ Flourishing } & \multicolumn{2}{|c|}{$\begin{array}{l}\text { Satisfacion } \\
\text { with Life }\end{array}$} & \multicolumn{2}{|c|}{$\begin{array}{c}\text { Panas } \\
\text { Positive }\end{array}$} & \multicolumn{2}{|c|}{$\begin{array}{c}\text { Panas } \\
\text { Negative }\end{array}$} \\
\hline & & $\%$ & $\chi^{2}$ & $\%$ & $\chi^{2}$ & $\%$ & $x^{2}$ & $\%$ & $x^{2}$ \\
\hline Sex & $\begin{array}{c}\text { Male } \\
\text { Female }\end{array}$ & $\begin{array}{l}56.5 \% \\
45.8 \%\end{array}$ & $9.73 * * *$ & & ns & $\begin{array}{l}66.0 \% \\
46.4 \%\end{array}$ & $32.48^{* * *}$ & $\begin{array}{l}31.2 \% \\
51.4 \%\end{array}$ & $34.61^{* * *}$ \\
\hline Status & $\begin{array}{c}\text { Single } \\
\text { Relationship } \\
\text { Married } \\
\text { Divorced } \\
\text { Widow }\end{array}$ & & ns & $\begin{array}{l}39.5 \% \\
48.7 \% \\
52.3 \% \\
39.1 \% \\
40.0 \%\end{array}$ & $17.60^{* * *}$ & & ns & $\begin{array}{l}50.3 \% \\
53.9 \% \\
35.1 \% \\
30.4 \% \\
40.0 \%\end{array}$ & $34.82 * * *$ \\
\hline Occupation & $\begin{array}{c}\text { Unemployed } \\
\text { Student } \\
\text { Autonomous } \\
\text { Public } \\
\text { Private } \\
\text { Retired }\end{array}$ & $\begin{array}{l}51.9 \% \\
48.6 \% \\
46.2 \% \\
44.0 \% \\
45.7 \% \\
19.2 \%\end{array}$ & 11.44 * & $\begin{array}{l}34.5 \% \\
46.9 \% \\
46.8 \% \\
42.9 \% \\
51.3 \% \\
57.7 \%\end{array}$ & $18.06^{* * *}$ & $\begin{array}{l}39.6 \% \\
50.6 \% \\
55.8 \% \\
40.5 \% \\
54.0 \% \\
53.8 \%\end{array}$ & $17.42^{* * *}$ & $\begin{array}{l}50.2 \% \\
53.7 \% \\
41.7 \% \\
35.7 \% \\
42.1 \% \\
19.2 \%\end{array}$ & $30.57^{* * *}$ \\
\hline Cohabiting & $\begin{array}{l}\text { Alone } \\
\text { Partner } \\
\text { Family } \\
\text { Friends }\end{array}$ & & ns & & ns & & ns & $\begin{array}{l}46.0 \% \\
39.6 \% \\
50.1 \% \\
49.2 \%\end{array}$ & $8.78 *$ \\
\hline $\begin{array}{l}\text { COVID19 } \\
\text { Vulnerables }\end{array}$ & $\begin{array}{l}\text { Yes } \\
\text { Nos }\end{array}$ & & ns & & ns & & ns & $\begin{array}{l}55.9 \% \\
47.2 \%\end{array}$ & $4.34 *$ \\
\hline
\end{tabular}

$$
{ }^{*}: p .<0.05 ;{ }^{* * *}: p .<0.001 .
$$




\subsection{Psychological COVID-19 Impact Evaluation}

We assessed the impact of Covid-19 through a comparison with the reference data of the psychological dimensions considered, from validation studies that were made regarding Italian samples before the emergency arose (Table 5). The only exception are the data coming from the GRiPS, which were compared with its original validation. The comparison of the data showed higher self efficacy $(M=35.56 ; D S=6.5)$, virtual sense of community $(M=40.7 ; D S=14.8)$, and locus of control $(M=40.21 ; D S=7.5)$, which seems to be more external when compared to the reference one. Both of the dimensions of PANAS seem to have increased as compared to the reference sample, with a simultaneous manifestation of positive $(M=30.17 ; D S=7.4)$ and negative emotions $(M=24.07$; $D S=7.1$ ). Table A1 shows a reduction in Social Connectedness $M=83.5 ; D S=16.7$ ) and in a general propensity risk of the sample $(M=1.9 ; D S=0.6)$. Well-being is generally lowered, in both the eudaimonic dimension $(M=20.64 ; D S=8.1)$ and hedonic $(M=15.78 ; D S=4.6)$.

Table 5. COVID-19 impact evaluation: comparisons between respondent results and reference data on the investigated psychological measures. A comparison between the sample's data and the data from the reference samples. The empirical sample size is always 1556.

\begin{tabular}{|c|c|c|c|c|c|c|}
\hline Dimension & $\begin{array}{c}\text { Empirical } \\
\text { Data }\end{array}$ & $\begin{array}{c}\text { Reference } \\
\text { Data }\end{array}$ & $\begin{array}{c}\text { Reference } \\
\text { Sample Size }\end{array}$ & $\begin{array}{c}\text { Means } \\
\text { Difference }\end{array}$ & $\begin{array}{c}\text { Student } \\
t\end{array}$ & $\begin{array}{c}\text { Hedges } \\
g\end{array}$ \\
\hline Self Efficacy & 35.56 & $28.28[34]$ & 176 & $25.7 \%$ & $14.46^{* * *}$ & 1.15 \\
\hline External LOC & 40.21 & $27.00[36]$ & 139 & $48.9 \%$ & $19.50 * * *$ & 1.73 \\
\hline Social Connectedness & 83.50 & $91.00[38]$ & 197 & $-8.2 \%$ & $-6.05^{* * *}$ & -0.46 \\
\hline Virtual SOC & 40.71 & $27.01[40]$ & 394 & $50.7 \%$ & $17.78^{* * *}$ & 1.01 \\
\hline Flourishing & 20.64 & $38.33[42]$ & 466 & $-46.1 \%$ & $-39.96^{* * *}$ & -2.11 \\
\hline PANAS Positive & 30.17 & $27.60[44]$ & 600 & $9.3 \%$ & $7.33^{p} \leq 0.001$ & 0.35 \\
\hline PANAS Negative & 24.07 & $16.00[44]$ & 600 & $50.4 \%$ & $24.47 * * *$ & 1.18 \\
\hline Satisfaction with life & 17.78 & $23.28[46]$ & 464 & $-32.2 \%$ & $-28.67^{* * *}$ & -1.63 \\
\hline Risk Propensity & 1.90 & $2.30[47]$ & 233 & $-17.4 \%$ & $-8.80^{* * *}$ & -0.67 \\
\hline
\end{tabular}

\subsection{Correlations between Psychological Criteria}

Finally, we considered the correlations between the psychological dimensions that were considered by the study in order to have a global overview of the participants' psychological state (Table 6).

First of all, the correlation analysis shows a negative association between self efficacy and internal locus of control, which had already emerged in previous analysis: our data reveal a small but significant positive association between external locus of control and self efficacy.

Self efficacy positively correlated with satisfaction with life and positive emotions. Peculiarly, a positive association emerged between External Locus of Control, satisfaction with life, and positive emotions. In our sample, the more people externalized the control over the situation, the greater their satisfaction with life and emotional positive arousal.

Social Connectedness is the psycho-social dimension that was more directly impacted by the lockdown. In line with the Social Capital Theory [50], our data show a positive association between social connectedness and self efficacy, and between social connectedness and external locus of control.

In our results we also see how the average social connectedness of citizens decreased during lockdown, but an increase in the usage of social networks and social media was also observed. Social connectedness is correlated with positive emotions and satisfaction with life, and the virtual sense of community seems to be the best predictor of flourishing. Finally, the general risk propensity of people only revealed a small negative association with flourishing. 
Table 6. Correlations between psychological dimensions.

\begin{tabular}{|c|c|c|c|c|c|c|c|c|}
\hline Dimension & 1 & 2 & 3 & 4 & 5 & 6 & 7 & 8 \\
\hline \multicolumn{9}{|l|}{ 1- Self Efficacy } \\
\hline 2- Locus of Control (Ext) & $0.22^{(p .<0.001)}$ & & & & & & & \\
\hline 3- Social Connectedness & $0.37^{(p .<0.001)}$ & $0.28^{(p .<0.001)}$ & & & & & & \\
\hline 4- Virtual Sense of Community & $\left.-0.04^{(p .}=0.158\right)$ & $-0.03^{(p .=0.293)}$ & $-0.15^{(p .<0.001)}$ & & & & & \\
\hline 5- Flourishing & $-0.16^{(p .<0.001)}$ & $-0.14^{(p .<0.001)}$ & $-0.19^{(p .<.001)}$ & $0.36^{(p .<0.001)}$ & & & & \\
\hline 6- Panas Positive & $0.46^{(p .<0.001)}$ & $0.21^{(p .<0.001)}$ & $0.36^{(p .<.001)}$ & $\left.-0.02^{(p .}=0.428\right)$ & $-0.09(p .<0.001)$ & & & \\
\hline 7- Panas Negative & $-0.39^{(p .<0.001)}$ & $-0.42^{(p .<0.001)}$ & $-0.33^{(p .<0.001)}$ & $\left.0.02^{(p .}=0.482\right)$ & $0.14^{(p .<0.001)}$ & $-0.37^{(p .<0.001)}$ & & \\
\hline 8- Satisfaction with life & $0.37^{(p .<0.001)}$ & $0.22^{(p .<0.001)}$ & $0.45^{(p .<0.001)}$ & $-0.07^{(p .<0.007)}$ & $-0.17^{(p .<0.001)}$ & $0.44^{(p .<0.001)}$ & $-0.36^{(p .<0.001)}$ & \\
\hline 9- General Risk Propensity & $-0.06^{(p .=0.012)}$ & $0.01^{(p .=0.982)}$ & $-0.04^{(p .=0.080)}$ & $-0.13^{(p .<0.001)}$ & $-0.25^{(p .<0.001)}$ & $-0.11^{(p .<0.001)}$ & $0.01^{(p .=0.855)}$ & $\left.-0.04^{(p .}=0.124\right)$ \\
\hline
\end{tabular}




\section{Discussion}

The WHO declared COVID-19 as a global pandemic on March 11 2020, after the first coronavirus cases in Wuhan: the emergency caused a significant impact socio-economic and psychological dimensions, in addition to the growing number of infected and deaths.

Previous studies already highlighted the impact of COVID-19 on general well-being and mental health [16]: in line with the wide literature that is currently available about the impact of COVID-19, we found a reduction in some of the dimensions that are associated with well-being, such as Flourishing and Satisfaction with Life. We observed an impact on both, with an effect of $-46.1 \%$ on Flourishing and $-32.2 \%$ on satisfaction with life. These findings agree with studies that were previously conducted in China during the peak of the lockdown. Studies found a lower satisfaction with life that was presumably due to both the uncertainty of the situation and the measures that the population was required to follow: albeit useful and necessary to slow down the spreading of the infection, the fact that they're so limiting might have made quality of life exponentially worse, as people were neither allowed to go out for personal leisure nor could some of them work at all, as many workplaces were closed down and some even lost their job [51].

Beyond the common reference to well-being and other health related dimensions (e.g., depression, post-traumatic stress disorder, anxiety), literature has not yet investigated how the COVID emergency impacted many fundamental psychological mechanics. In particular, the agentivity of the subjects and their individual resilience perception (i.e., locus of control and self efficacy), their risk perception tendencies, their real and virtual social connectedness, as well as their emotional activation have never been studied as early indicators of well-being (i.e., satisfaction with life, flourishing) for the Italian population.

Moreover, despite previous studies having investigated well-being in the Italian population after the impact of COVID [25-27], none of them considered the dimensions that were taken into account in our study, and none of them conducted the study in a condition of total anonymity in order to promote stronger real self disclosure as well [30,31]. Anonymity might also have other benefits, like a potential decrease in social desirability when replying to the online survey [32].

According to the literature, the lockdown can be related to the perception of loneliness and boredom, which can have harmful effects on physical and mental well-being if it is experienced for extended periods of time [52].

Collected data allowed for confirming how social isolation that was caused by the lockdown in Italy strongly influenced individuals; many people spent the lockdown alone or with minimal social contact, reporting a significant reduction in social connectedness $(-8.2 \%)$.

Nevertheless, unlike previous pandemics, COVID-19 happened in a world that is largely dominated by ICT (e.g., Social networks, social media ...), and these technologies seem to have played a protective role in Italy, compensating for the reduced social connectedness through/by an increase in the sense of virtual community perception (50.7\%).

The lower social capital perceived by respondents, combined with the uncertainty regarding the development of a cure and the actual danger posed by the illness, might explain the revealed change in risk propensity. In line with international literature [53], for the Italian population, too, experimental data confirmed a decrease in risk propensity of around $17.4 \%$ during the lockdown.

Furthermore, these conditions should also cause the locus of control to be more external, but if that were the case, then self efficacy should also be lower [54]. However, on the contrary, we found that the correlation between a more external locus of control and self efficacy seems to be not significant in our sample.

In line with literature, we confirm, even for the Italian population, a significantly more external locus of control. In particular, Vijayaraghavan and SINGHAL [55] addressed such an effect as a consequence of the containment measures that were established by the the government, and the tendency to follow what government says is right in order to fight the spread of the virus, more than an effect of the reduced self efficacy. In the same way, according to literature [55], we can interpret 
our results regarding locus of control as an effect of an increased perception of social support by the government.

This would be a confirmation of our data, since we observed a relevant change in external locus of control (48.9\%), with it being more external than before the lockdown, and a surprising increase in self-efficacy $(25.7 \%)$.

At the same time, the peculiar increase in general self efficacy, which goes against our initial hypothesis, might be explained in terms of response to the feeling of uncertainty that was generated by COVID-19 and the reduced internal locus of control. Zhang et al. [56] underline a positive relationship between self-efficacy and uncertainty in terms of increasing self-care behaviors in specific populations who find themselves in a state of illness. Accordingly, when considering how the containment measures provided a way to increase self-care behaviours, it is plausible to interpret our experimental data in the direction of those from Zhang and colleagues Zhang et al. [56].

Finally, the emotional activation of the Italian population seems to have increased mostly in terms of negative emotions (50.4\%). These may have helped to manage the lockdown: effective threat management strategies and health-related behaviors are sometimes created as a result of emotional responses to the problem. People experiencing a crisis build a mental threat assessment model, so that they can better understand the event [24]. Although small, there is also an increase in positive emotions (9.3\%). Conforming to social distancing while simultaneously taking part in national identity affirming behaviors seems to have an indirect effect on positive affects, increasing them [57]. In our case, we can hypothesize that this is due to a phenomenon that occurred in Italy during the quarantine: people started to sing and dance to popular folk songs and the Italian anthem as well as wave Italian flags from their balconies; this could have caused a similar effect to the one that was stated by Kachanoff et al. [57]. Therefore, taking part in identity affirming behavior can be a way to cope with the isolation period.

Some observations carried out in different cultures [58,59] for what concern the impact of COVID-19 on psychological dimensions have also been confirmed for the Italian reality. However, this study also explored both the magnitude of such effects for the Italian population, as well as some aspects that, to our knowledge, are yet to be examined in relation to the COVID-19 emergency. In particular, we took virtual sense of community and social connectedness into account to analyze variations in social dynamics, flourishing to add further dimensionality to well-being, and GRiPS in order to obtain a general idea regarding how much people took part in health preventive behaviors or had a propensity for taking risks.

This study also presents some limitations. There is a possible selection bias due to the fact that our sample was, probably, mostly composed of digitally literate subjects that tended to have a lower average age than the general Italian population; therefore, it might not be representative of the Italian population at large. In particular, the average age is quite low, the education level is quite high, and we observed a prevalence of female respondents with a small number of divorced and widowed respondents and retired people, as shown in Table 1: most of our sample, in fact, seems to be consisting of students and people living with their families. Nevertheless, the sample could still be considered to be quite representative of active internet users.

The COVID-19 emergency took a peculiar form on the Italian society: the Government issued strict limitations that brought the entire country to a standstill, during one of the most severe epidemics of contemporary Italian history. In general, we estimated the magnitude of its impact, and we isolated some elements that appeared to be fundamental in describing coping strategies that the Italian population took part in, such as manifestations of solidarity and national identity that spread through the whole country.

Therefore, our study could represent a starting point for developing possible interventions for the general population, and for designing social policies from now onward to mitigate the impact of future pandemics (e.g., the COVID-19 subsequent waves).

In particular, our results suggested how self efficacy and locus of control should be improved by a reliable, accessible, and effective knowledge and information support, provided by a trusted source 
both in terms of expertise and honesty [60]. The quality and accessibility of provided knowledge and abilities would effectively support the self efficacy perception; while a perception of trust, expertise, and honesty for what concerns the source of information and social policies, would effectively sustain a "sane" externalization of locus of control.

Some results appear to be contradictory, in particular the decrease in social connectedness and the increase virtual sense of community. Nevertheless, a possible interpretation could be that the two dimensions, that are usually correlated, because of the lockdown and the peculiar situation un-correlated as a compensatory phenomenon strategy effect. Because of lockdown and quarantine, we can speculate that respondents experienced a reduction in social connectedness, while partially trying to compensate it with an increase in engagement in virtual communities.

\section{Conclusions}

While the social policies that were designed in Europe to face with the first COVID-19 wave positively impacted, even if moderately, some critic citizens' psychological dimensions, such as self efficacy and locus of control, nothing was done to actively support the lack of social connectedness because of the lockdown, and the development of a (positive) virtual sense of community. New, and probably courageous social policies should take into account these two last fundamental dynamics, exploiting the opportunities provided by the web to develop and improve the citizens' digital capital [61], as well as designing the opportunities for brand new "real" social connections.

The previous suggestions would, of course, have an impact on just a fraction of the complex social interventions that are required by a possible new pandemic; nevertheless, empirical data suggested how they should support a positive emotional activation and an increase in satisfaction with life. Moreover, such a composite intervention would promise to facilitate a greater engagement and compliance with possible new government issued regulations [62], as well as increase community resilience.

Author Contributions: A.P., L.M. and A.G. envisaged the work and design the methodology. A.P. and L.M. revised the recent literature and produced the state of the art. A.G., A.P. and L.M. designed and implemented the survey. A.G. analyzed the data and prepared the figures. All the authors contributed to the interpretation of the results. A.P. and L.M. wrote the introduction, A.G. wrote the methodological sections. All the authors contributed to the discussion section, and revised the entire manuscript. All authors have read and agreed to the published version of the manuscript.

Funding: This research received no external funding.

Acknowledgments: The authors thank Mirko Duradoni for the precious insights and revision of the paper, and Maria Martina Fiorenza for the fundamental support during the data collection.

Conflicts of Interest: The authors declare there is no conflict of interest.

Ethics Committee Approval: Expedited ethics approval was obtained from the Ethics Committee of the University of Florence (protocol number: 0092811).

\section{Appendix A}

Table A1. Descriptive statistics for psychological dimensions of the sample.

\begin{tabular}{lcccc}
\hline Psychological Dimension & Mean & S.D. & Skeweness & Kurtosis \\
\hline Self Efficacy & 35.56 & 6.50 & -0.18 & 0.02 \\
External LOC & 40.21 & 7.52 & -0.14 & 0.15 \\
Social Connectedness & 83.50 & 16.69 & -0.56 & 0.21 \\
Virtual SOC & 40.71 & 14.81 & 0.39 & -0.84 \\
Flourishing & 20.64 & 8.08 & 0.53 & -0.63 \\
PANAS Positive & 30.17 & 7.36 & -0.09 & -0.32 \\
PANAS Negative & 24.07 & 6.15 & 0.58 & 0.20 \\
Satisfaction with life & 15.78 & 4.62 & -0.24 & -0.57 \\
Risk Propensity & 1.90 & 0.60 & -0.34 & -0.91 \\
\hline
\end{tabular}




\section{References}

1. WHO. WHO Director-General's Opening Remarks at the Media Briefing On COVID-19. Available online: https:/ / www.who.int/dg/speeches/detail/who-director-general-s-opening-remarksat-the-media-briefing-on-covid-19---11-march-2020 (accessed on 11 March 2020).

2. Ministero della Salute. Covid-19-Situazione in Italia. Available online: http://www.salute.gov.it/ portale/nuovocoronavirus/dettaglioContenutiNuovoCoronavirus.jsp? area=nuovoCoronavirus\&id= 5351\&lingua=italiano\&menu=vuoto (accessed on 15 July 2020).

3. Lazzerini, M.; Putoto, G. COVID-19 in Italy: Momentous decisions and many uncertainties. Lancet Glob. Health 2020, 8, e641-e642. [CrossRef]

4. Deaton, A. The financial crisis and the well-being of Americans 2011 OEP Hicks Lecture. Oxf. Econ. Pap. 2012, 64, 1-26. [CrossRef]

5. Latif, E. Crisis, unemployment and psychological wellbeing in Canada. J. Policy Model. 2010, 32, 520-530. [CrossRef]

6. Usher, K.; Bhullar, N.; Jackson, D. Life in the pandemic: Social isolation and mental health. J. Clin. Nurs. 2020. [CrossRef] [PubMed]

7. Depoux, A.; Martin, S.; Karafillakis, E.; Preet, R.; Wilder-Smith, A.; Larson, H. The Pandemic of Social Media Panic Travels Faster than the COVID-19 Outbreak. 2020. Available online: https:/ /www.ncbi.nlm.nih.gov/ pmc/articles/PMC7107516/ (accessed on 9 December 2020).

8. Liu, S.; Yang, L.; Zhang, C.; Xiang, Y.T.; Liu, Z.; Hu, S.; Zhang, B. Online mental health services in China during the COVID-19 outbreak. Lancet Psychiatry 2020, 7, e17-e18. [CrossRef]

9. Dufty, N. Using social media to build community disaster resilience. Aust. J. Emerg. Manag. 2012, $27,40-45$.

10. Wang, C.; Pan, R.; Wan, X.; Tan, Y.; Xu, L.; Ho, C.S.; Ho, R.C. Immediate psychological responses and associated factors during the initial stage of the 2019 coronavirus disease (COVID-19) epidemic among the general population in China. Int. J. Environ. Res. Public Health 2020, 17, 1729. [CrossRef]

11. Frenkel, S.; Alba, D.; Zhong, R. Surge of virus misinformation stumps Facebook and Twitter. New York Times, 9 March 2020.

12. Qiu, J.; Shen, B.; Zhao, M.; Wang, Z.; Xie, B.; Xu, Y. A nationwide survey of psychological distress among Chinese people in the COVID-19 epidemic: Implications and policy recommendations. Gen. Psychiatry 2020, 33, e100213. [CrossRef]

13. Swar, B.; Hameed, T.; Reychav, I. Information overload, psychological ill-being, and behavioral intention to continue online healthcare information search. Comput. Hum. Behav. 2017, 70, 416-425. [CrossRef]

14. Li, J.B.; Yang, A.; Dou, K.; Cheung, R.Y. Self-Control Moderates the Association between Perceived Severity of the Coronavirus Disease 2019 (COVID-19) and Mental Health Problems among the Chinese Public. 2020. Available online: https:/ / www.mdpi.com/1660-4601/17/13/4820 (accessed on 9 December 2020).

15. Zhang, W.R.; Wang, K.; Yin, L.; Zhao, W.F.; Xue, Q.; Peng, M.; Min, B.Q.; Tian, Q.; Leng, H.X.; Du, J.L.; et al. Mental health and psychosocial problems of medical health workers during the COVID-19 epidemic in China. Psychother. Psychosom. 2020, 89, 242-250. [CrossRef]

16. Ahmed, M.Z.; Ahmed, O.; Aibao, Z.; Hanbin, S.; Siyu, L.; Ahmad, A. Epidemic of COVID-19 in China and associated Psychological Problems. Asian J. Psychiatry 2020, 102092. [CrossRef]

17. Gunnell, D.; Appleby, L.; Arensman, E.; Hawton, K.; John, A.; Kapur, N.; Khan, M.; O'Connor, R.C.; Pirkis, J.; Caine, E.D.; et al. Suicide risk and prevention during the COVID-19 pandemic. Lancet Psychiatry 2020, 7, 468-471. [CrossRef]

18. Huang, Y.; Zhao, N. Generalized anxiety disorder, depressive symptoms and sleep quality during COVID-19 outbreak in China: A web-based cross-sectional survey. Psychiatry Res. 2020, 112954. [CrossRef]

19. Odriozola-González, P.; Planchuelo-Gómez, Á.; Irurtia-Muñiz, M.J.; de Luis-García, R. Psychological Symptoms of the Outbreak of the COVID-19 Crisis and Confinement in the Population of Spain. 2020. Available online: https:/ /journals.sagepub.com/doi/pdf/10.1177/1359105320967086 (accessed on 9 December 2020).

20. Xiao, H.; Zhang, Y.; Kong, D.; Li, S.; Yang, N. The effects of social support on sleep quality of medical staff treating patients with coronavirus disease 2019 (COVID-19) in January and February 2020 in China. Med. Sci. Monit. Int. Med J. Exp. Clin. Res. 2020, 26, e923549-1. 
21. Dunning, A.; Pownall, M. Dispositional and Situational Attribution of COVID-19 Risk: A Content Analysis of Response Typology. 2020. Available online: https:/ / psyarxiv.com/czskd/ (accessed on 9 December 2020).

22. Polizzi, C.; Lynn, S.J.; Perry, A. Stress and Coping in the Time of Covid-19: Pathways to Resilience and Recovery. Clin. Neuropsychiatry 2020, 17, 59-62.

23. Varshney, L.R.; Socher, R. COVID-19 Growth Rate Decreases with Social Capital. medRxiv 2020. [CrossRef]

24. Bish, A.; Michie, S. Demographic and attitudinal determinants of protective behaviours during a pandemic: A review. Br. J. Health Psychol. 2010, 15, 797-824. [CrossRef] [PubMed]

25. Mazza, C.; Ricci, E.; Biondi, S.; Colasanti, M.; Ferracuti, S.; Napoli, C.; Roma, P. A nationwide survey of psychological distress among italian people during the COVID-19 pandemic: Immediate psychological responses and associated factors. Int. J. Environ. Res. Public Health 2020, 17, 3165. [CrossRef] [PubMed]

26. Favieri, F.; Forte, G.; Tambelli, R.; Casagrande, M. The Italians in the Time of Coronavirus: Psychosocial Aspects of Unexpected COVID-19 Pandemic. Available online: https:/ /www.researchgate.net/publication/ 341018673_The_Italians_in_the_Time_of_Coronavirus_Psychosocial_Aspects_of_Unexpected_COVID-19_ Pandemic (accessed on 13 December 2020).

27. Cerami, C.; Santi, G.C.; Galandra, C.; Dodich, A.; Cappa, S.F.; Vecchi, T.; Crespi, C. Covid-19 Outbreak in Italy: Are We Ready for the Psychosocial and the Economic Crisis? Baseline Findings From the PsyCovid Study. Front. Psychiatry 2020, 11, 556. [CrossRef]

28. Gazzetta Ufficiale. DECRETO-LEGGE 9 Marzo 2020, n. 14 Disposizioni Urgenti per il Potenziamento del Servizio Sanitario Nazionale in Relazione All'emergenza COVID-19. (20G00030) (GU Serie Generale n.62 del 09-03-2020). Available online: https:/ / www.gazzettaufficiale.it/eli/id/2020/03/09/20G00030/sg (accessed on 10 March 2020).

29. Goodman, L.A. Snowball sampling. Ann. Math. Stat. 1961, 32, 148-170. [CrossRef]

30. Joinson, A.N. Self-disclosure in computer-mediated communication: The role of self-awareness and visual anonymity. Eur. J. Soc. Psychol. 2001, 31, 177-192. [CrossRef]

31. Tidwell, L.C.; Walther, J.B. Computer-mediated communication effects on disclosure, impressions, and interpersonal evaluations: Getting to know one another a bit at a time. Hum. Commun. Res. 2002, 28, 317-348. [CrossRef]

32. Joinson, A. Social desirability, anonymity, and Internet-based questionnaires. Behav. Res. Methods, Instruments Comput. 1999, 31, 433-438. [CrossRef] [PubMed]

33. Schwarzer, R.; Jerusalem, M. Generalized self-efficacy scale. Meas. Health Psychol. User'S Portfolio. Causal Control. Beliefs 1995, 1, 35-37.

34. Guazzini, A.; Imbimbo, E.; Stefanelli, F.; Bravi, G. The Online Bystander Effect: Evidence from a Study on Synchronous Facebook Communications. In Proceedings of the International Conference on Internet Science; Springer: Berlin/Heidelberg, Germany, 2019; pp. 153-167.

35. Craig, A.R.; Franklin, J.A.; Andrews, G. A scale to measure locus of control of behaviour. Br. J. Med. Psychol. 1984, 57, 173-180. [CrossRef]

36. Farma, T.; Cortivonis, I. Un questionario sul "locus of control": Suo utilizzo nel contesto italiano (A questionnaire on the locus of control: Its use in the italian context). Ric. Psicoter. 2000, 3, 147-155.

37. Lee, R.M.; Robbins, S.B. Measuring belongingness: The social connectedness and the social assurance scales. J. Couns. Psychol. 1995, 42, 232. [CrossRef]

38. Capanna, C.; Stratta, P.; Collazzoni, A.; D’Ubaldo, V.; Pacifico, R.; Di Emidio, G.; Ragusa, M.; Rossi, A. Social connectedness as resource of resilience: Italian validation of the Social Connectedness Scale-Revised. J. Psychopathol. 2013, 19, 320-326.

39. Blanchard, A.L. Developing a sense of virtual community measure. Cyberpsychol. Behav. 2007, 10, 827-830. [CrossRef]

40. Guazzini, A.; Duradoni, M.; Capelli, A.; Meringolo, P. An explorative model to assess individuals' phubbing risk. Future Internet 2019, 11, 21. [CrossRef]

41. Diener, E.; Wirtz, D.; Tov, W.; Kim-Prieto, C.; Choi, D.w.; Oishi, S.; Biswas-Diener, R. New well-being measures: Short scales to assess flourishing and positive and negative feelings. Soc. Indic. Res. 2010, 97, 143-156. [CrossRef]

42. Giuntoli, L.; Ceccarini, F.; Sica, C.; Caudek, C. Validation of the Italian versions of the flourishing scale and of the scale of positive and negative experience. Sage Open 2017, 7. [CrossRef] 
43. Watson, D.; Clark, L.A.; Tellegen, A. Development and validation of brief measures of positive and negative affect: The PANAS scales. J. Personal. Soc. Psychol. 1988, 54, 1063. [CrossRef]

44. Terraciano, A.; McCrae, R.R.; Costa, P.T., Jr. Factorial and construct validity of the Italian Positive and Negative Affect Schedule (PANAS). Eur. J. Psychol. Assess. 2003, 19, 131. [CrossRef]

45. Diener, E.; Emmons, R.A.; Larsen, R.J.; Griffin, S. The satisfaction with life scale. J. Personal. Assess. 1985, 49, 71-75. [CrossRef] [PubMed]

46. Di Fabio, A.; Gori, A. Measuring adolescent life satisfaction: Psychometric properties of the satisfaction with life scale in a sample of Italian adolescents and young adults. J. Psychoeduc. Assess. 2016, 34, 501-506. [CrossRef]

47. Zhang, D.C.; Highhouse, S.; Nye, C.D. Development and validation of the general risk propensity scale (GRiPS). J. Behav. Decis. Mak. 2019, 32, 152-167. [CrossRef]

48. Hedges, L.V.; Olkin, I. Statistical Methods in Meta-Analysis. 1985. Available online: https: //www.researchgate.net/publication/216811655_Statistical_Methods_in_Meta-Analysis (accessed on 9 December 2020).

49. Changyong, F.; Hongyue, W.; Naiji, L.; Tian, C.; Hua, H.; Ying, L.; Tu, X.M. Log-transformation and its implications for data analysis. Shanghai Arch. Psychiatry 2014, 26, 105.

50. Haslam, C.; Cruwys, T.; Haslam, S.A.; Jetten, J. Social connectedness and health. Encycl. Geropsychol. 2015, 2015, 46-1.

51. Li, S.; Wang, Y.; Xue, J.; Zhao, N.; Zhu, T. The impact of COVID-19 epidemic declaration on psychological consequences: A study on active Weibo users. Int. J. Environ. Res. Public Health 2020, 17, 2032. [CrossRef]

52. Wilson, R.S.; Krueger, K.R.; Arnold, S.E.; Schneider, J.A.; Kelly, J.F.; Barnes, L.L.; Tang, Y.; Bennett, D.A. Loneliness and risk of Alzheimer disease. Arch. Gen. Psychiatry 2007, 64, 234-240. [CrossRef] [PubMed]

53. Bu, D.; Hanspal, T.; Liao, Y.; Liu, Y. Risk taking during a global crisis: Evidence from wuhan. Covid Econ. 2020, 5, 106-146.

54. Judge, T.A.; Erez, A.; Bono, J.E.; Thoresen, C.J. Are measures of self-esteem, neuroticism, locus of control, and generalized self-efficacy indicators of a common core construct? J. Personal. Soc. Psychol. 2002, 83, 693. [CrossRef]

55. Vijayaraghavan, P.; Singhal, D. A Descriptive Study of Indian General Public's Psychological Responses during COVID-19 Pandemic Lockdown Period in India. 2020. Available online: https:/ / www.researchgate.net/publication/340627047_A_Descriptive_Study_of_Indian_General_ Public\%27s_Psychological_responses_during_COVID-19_Pandemic_Lockdown_Period_in_India (accessed on 9 December 2020).

56. Zhang, Y.; Kwekkeboom, K.; Petrini, M. Uncertainty, self-efficacy, and self-care behavior in patients with breast cancer undergoing chemotherapy in China. Cancer Nurs. 2015, 38, E19-E26. [CrossRef]

57. Kachanoff, F.; Bigman, Y.; Kapsaskis, K.; Gray, K. Measuring Two Distinct Psychological Threats of COVID-19 and Their Unique Impacts on Wellbeing and Adherence to Public Health Behaviors. 2020. Available online: https:/ /journals.sagepub.com/doi/pdf/10.1177/1948550620931634 (accessed on 9 December 2020).

58. Fiorillo, A.; Gorwood, P. The consequences of the COVID-19 pandemic on mental health and implications for clinical practice. Eur. Psychiatry 2020, 63. [CrossRef]

59. Montemurro, N. The emotional impact of COVID-19: From medical staff to common people. Brain Behav. Immun. 2020. [CrossRef]

60. Eagly, A.H.; Wood, W.; Chaiken, S. Causal inferences about communicators and their effect on opinion change. J. Personal. Soc. Psychol. 1978, 36, 424. [CrossRef]

61. Wellman, B.; Haase, A.Q.; Witte, J.; Hampton, K. Does the Internet increase, decrease, or supplement social capital? Social networks, participation, and community commitment. Am. Behav. Sci. 2001, 45, 436-455. [CrossRef]

62. Barkworth, J.M.; Murphy, K. Procedural justice policing and citizen compliance behaviour: The importance of emotion. Psychol. Crime Law 2015, 21, 254-273. [CrossRef]

Publisher's Note: MDPI stays neutral with regard to jurisdictional claims in published maps and institutional affiliations. 